\title{
Beta protein 1 homeoprotein induces cell growth and estrogen- independent tumorigenesis by binding to the estrogen receptor in breast cancer
}

\author{
Sidney W. Fu', ${ }^{1,}$, Saurabh P. Kirolikar ${ }^{2, *}$, Erika Ginsburg ${ }^{3}$, Xiaohui Tan ${ }^{1}$, Arnold \\ Schwartz ${ }^{4}$, Samuel J. Simmens ${ }^{5}$, Yan-Gao Man', Joseph J. Pinzone7, Christine \\ Teal $^{8}$, Sanket Awate ${ }^{2}$, Barbara K. Vonderhaar ${ }^{3}$, Patricia E. Berg ${ }^{2}$ \\ ${ }^{1}$ Department of Medicine, Division of Genomic Medicine, George Washington University, Washington, DC 20037, USA \\ ${ }^{2}$ Department of Biochemistry and Molecular Medicine, George Washington University, Washington, DC 20037, USA \\ ${ }^{3}$ Mammary Biology and Tumorigenesis Laboratory, National Cancer Institute, National Institutes of Health, Bethesda, MD \\ 20892, USA \\ ${ }^{4}$ Department of Pathology, George Washington University Medical Center, Washington, DC 20037, USA \\ ${ }^{5}$ Department of Epidemiology and Biostatistics, School of Public Health and Health Services, George Washington University, \\ Washington, DC 20037, USA \\ ${ }^{6}$ Department of Gynecologic and Breast Pathology, Armed Forces Institute of Pathology, Washington, DC 20306, USA \\ ${ }^{7}$ David Geffen School of Medicine, UCLA, Los Angeles, CA 90095, USA \\ ${ }^{8}$ Department of Surgery, George Washington University, Washington, DC 20037, USA \\ *These authors contributed equally to this work \\ Correspondence to: Patricia E. Berg, email: peb@gwu.edu
}

Keywords: homeobox gene, BP1, estrogen receptor, tamoxifen resistance, tumorigenesis

Received: January 18, 2016

Accepted: July 06, 2016

Published: July 16, 2016

\section{ABSTRACT}

Expression of Beta Protein 1 (BP1), a homeotic transcription factor, increases during breast cancer progression and may be associated with tumor aggressiveness. In our present work, we investigate the influence of BP1 on breast tumor formation and size in vitro and in vivo. Cells overexpressing BP1 showed higher viability when grown in the absence of serum $(p<0.05)$, greater invasive potential $(p<0.05)$ and formed larger colonies $(p<0.004)$ compared with the controls. To determine the influence of BP1 overexpression on tumor characteristics, MCF-7 cells transfected with either empty vector (V1) or overexpressor plasmids ( 02 and 04 ) were injected into the fat pads of athymic nude mice. Tumors grew larger in mice receiving 02 or 04 cells than in mice receiving V1 cells. Moreover, BP1 mRNA expression levels were positively correlated with tumor size in patients $(p=0.01)$. Interestingly, $20 \%$ of mice injected with 02 or 04 cells developed tumors in the absence of estrogen, while no mice receiving $\mathrm{V} 1$ cells developed tumors. Several mechanisms of estrogen independent tumor formation related to BP1 were established. These data are consistent with the fact that expression of breast cancer anti-estrogen resistance 1 (BCAR1) was increased in 02 compared to V1 cells $(p<0.01)$. Importantly, 02 cells exhibited increased proliferation when treated with tamoxifen, while V1 cells showed growth inhibition. Overall, BP1 overexpresssion in MCF-7 breast cancer cells leads to increased cell growth, estrogen-independent tumor formation, and increased proliferation. These findings suggest that BP1 may be an important biomarker and therapeutic target in $E R$ positive breast cancer. 


\section{INTRODUCTION}

Beta Protein 1(BP1), an isoform of $D L X 4$, belongs to the homeobox family of genes, master regulatory genes implicated in early development and cell differentiation that are frequently deregulated in cancer [1,2]. Aberrant expression of $B P 1$ has been shown in women with breast cancer. $H O X B 7$-transduced $\mathrm{SkBr} 3$ cell lines developed tumors in nude mice in the absence of irradiation, while control mice injected with $\mathrm{SkBr} 3$ cells did not form tumors under those conditions [3]. Importantly, repression of HOXA5 in breast cancer resulted in the loss of expression of the tumor suppressor p53 [4]. Moreover, constitutive expression of HOXA1 in MCF7 cells led to increased anchorage-independent growth and tumor formation in mice [5]. BP1 directly activates the anti-apoptotic gene $B C L-2$ and results in resistance to $T N F-\alpha$. In sporadic breast cancer, $B P 1$ negatively regulates the expression of breast cancer anti-estrogen resistance 1 (BRCA1) through binding to its intron, suggesting that overexpression of $B P 1$ might be a potential inhibitor of $B R C A 1$. Therefore, targeting $B P 1$ may provide a new avenue for breast cancer management [6].

$B P 1$ belongs to the Distal-less subfamily of the homeobox gene family [7]. In our earlier study, $B P I$ expression was examined in untreated invasive ductal breast carcinoma (IDC) using semi-quantitative RT-PCR [8]. Overall, $B P 1$ mRNA expression was found in $80 \%$ of breast tumors, with an $11 \%$ rate of low $B P 1$ mRNA in normal tissues, while $100 \%$ of ER-negative tumors expressed $B P 1$. These data suggest $B P 1$ might be a useful target for therapy in patients with ER-negative tumors. In a follow-up study, we examined IDC cases from the Armed Forces Institute of Pathology which included women from around the world [9]. Eighty one percent of invasive ductal carcinomas were $B P 1$ positive by immunostaining, indicating excellent agreement between BP1 RNA expression (80\%) and protein expression (81\%).

Estrogens are crucial hormones involved not only in normal breast development but also in carcinogenesis of breast epithelium and progression of breast cancer [10]. Estrogens act through a specific receptor, the estrogen receptor (ER). Once activated by estrogen, ER forms a transcriptional complex with various co-activators and co-repressors on target gene promoters to regulate their expression [11] ER-negative breast cancers are unresponsive to anti-estrogen therapy. In general, these tumors have a higher histologic grade and a higher proliferative rate and are associated with poorer prognosis. In this paper we found estrogen independence associated with high BP1 expression in ER-positive tumors in cell lines and in mice. To determine the molecular mechanism that contributes in part or in whole to $B P 1$-related breast cancer aggressiveness in ER+ tumors, in vitro experiments were carried out. Here we present a novel model of $E R$ regulation and estrogen independence by $B P 1$.

\section{RESULTS}

\section{Increased levels of $B P 1$ are associated with a more aggressive phenotype in MCF-7 cells in vitro}

MCF-7 cells containing an empty vector (V1) or a plasmid stably overexpressing $B P 1$ cDNA under control of the CMV promoter (O2 and O4) were tested using classical assays which assess the oncogenic characteristics of cells. These cell lines were previously shown to express increased levels of BP1 mRNA and protein [12]. In the first assay, cells were grown in the absence of serum to test growth factor independence. By day seven in the absence of serum (Figure 1A), cell lines overexpressing $B P 1(\mathrm{O} 2$ and $\mathrm{O} 4)$ showed approximately two to three-fold higher viability compared with $\mathrm{V} 1$, a statistically significant difference $(p<0.05)$. These data suggest that high $B P 1$ levels may protect against cell death in the absence of serum, consistent with the increased $B C L-2$ expression in $B P 1$-overexpressing MCF-cells, as reported [12].

Growth in soft agar was utilized to determine the anchorage independent growth of $B P 1$ - transfected MCF- 7 cells. This assay is considered a reliable method for detecting the malignant potential of cells [13]. While the total number of colonies was similar for the cell lines $(\mathrm{V} 1=150, \mathrm{O} 2=161, \mathrm{O} 4=152)$, the cells overexpressing $B P 1$ produced larger and more rapidly growing colonies (Figure 1B and 1C). Ninety-five percent of the colonies formed by V1 cells were equal to or less than $0.2 \mathrm{~mm}$, while $88-93 \%$ of $\mathrm{O} 2$ and $\mathrm{O} 4$ colonies were greater than $0.2 \mathrm{~mm}$. Both the $\mathrm{O} 2$ and the $\mathrm{O} 4$ cell lines had a significantly higher distribution of colony sizes compared to the V1 cell lines ( $p<0.0001$, Wilcoxon Rank Sum test). Even by day 4, the colonies derived from $\mathrm{O} 2$ and $\mathrm{O} 4$ were noticeably larger than those from V1 (Figure 1C).

Whereas MCF-7 cells are poorly invasive through Matrigel [14], we wished to determine whether $B P 1$ could modulate their invasiveness. As shown in Figure 1D, O2 and $\mathrm{O} 4$ cells overexpressing $\mathrm{BP} 1$ increased invasion of MCF-7 cells by approximately 16 -fold compared with control V1 cells, which was statistically significant $(p<0.05)$. These data suggest that $B P 1$ levels may affect the metastatic potential of breast cancer, as previously demonstrated in ER-negative Hs578T breast cancer cells [15].

\section{Characteristics of tumor growth in mice}

It has previously been established that MCF-7 cells grow as a solid tumor when placed in the mammary glands of mice supplemented with estrogen [16]. To determine whether high $B P 1$ levels would influence tumor characteristics, we injected $\mathrm{V} 1, \mathrm{O} 2$ or $\mathrm{O} 4$ cells into cleared fat pads of athymic nude mice, with 10 mice per group. Palpable tumors were present at 45 days post-surgery in the mammary glands of mice supplemented with an estrogen 
pellet (Figure 2A). Due to the relatively small number of mice, data from mice injected with $\mathrm{O} 2$ and $\mathrm{O} 4$ cells were combined. Tumors derived from $\mathrm{O} 2$ and $\mathrm{O} 4$ cells, labeled BP1 (Figure 2A), appeared to grow at a faster rate and were larger by day 58 than tumors from control V1 cells, but the small number of tumors precluded significance testing. No distant metastases were observed for any mice at the time of sacrifice. $B P 1$ expression was retained in the tumors, shown by protein expression analysis. In mice supplemented with estrogen, $B P 1$ expression was higher in tumors derived from $\mathrm{O} 2$ and $\mathrm{O} 4$ cells than in tumors derived from V1 cells (Figure 2B, red staining cells).

\section{Human breast tumor size correlates with $B P 1$ expression}

The possible clinical relevance of $B P 1$ expression level with respect to tumor size in breast cancer patients was determined. Real-time PCR was used to measure

A

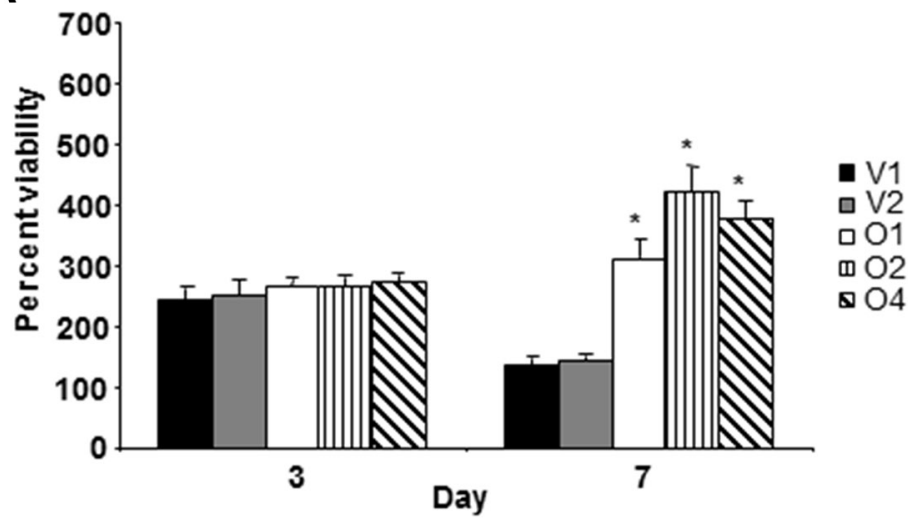

C

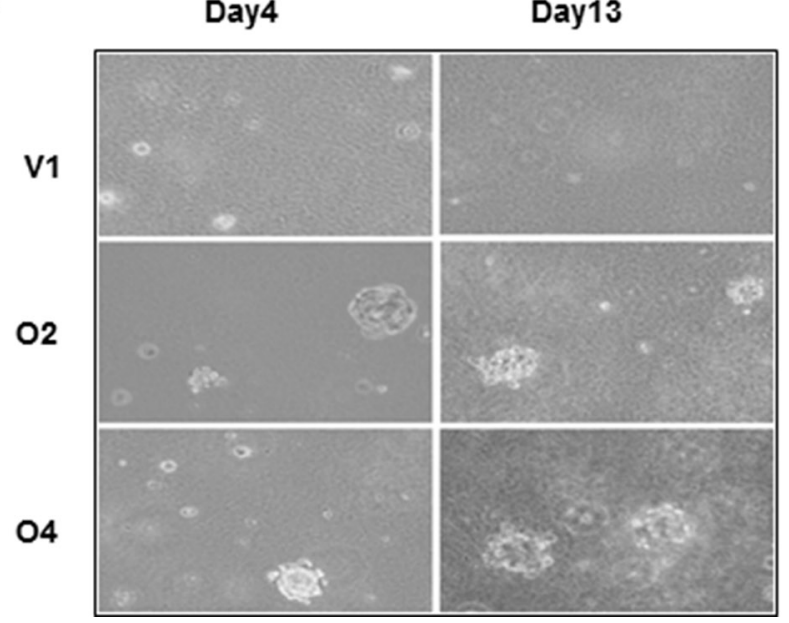

the levels of expression of $B P 1$ mRNA from 31 tumor samples. The levels of $B P 1$ expression, relative to $18 \mathrm{~S}$ RNA, ranged over 300-fold (Figure 3). For comparison, RNA was extracted from five normal breast tissues; BP1 levels ranged from 0.010 to 0.060 relative to $18 S$ RNA. We found a positive correlation $(r=0.40, p=0.02)$ between [log] BP1 expression and [log] tumor size. After statistically controlling for age and race, the partial correlation coefficient remained statistically significant (partial $r=0.49, p=0.01$ ). Thus, there is an association between higher BP1 mRNA expression levels and tumor size in patients.

\section{$B P 1$ expression is associated with estrogen independence}

In general, MCF-7 cells require exogenous estrogen to form tumors in nude mice [16]. However, approximately $20 \%$ of the mice implanted with cells

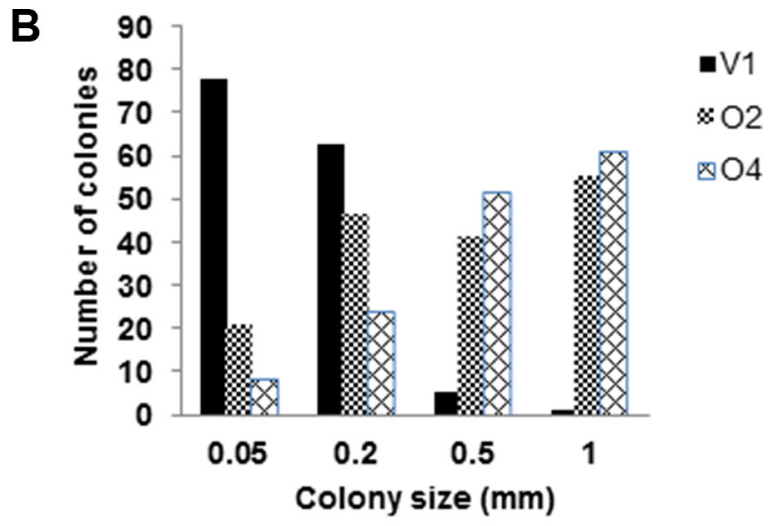

D

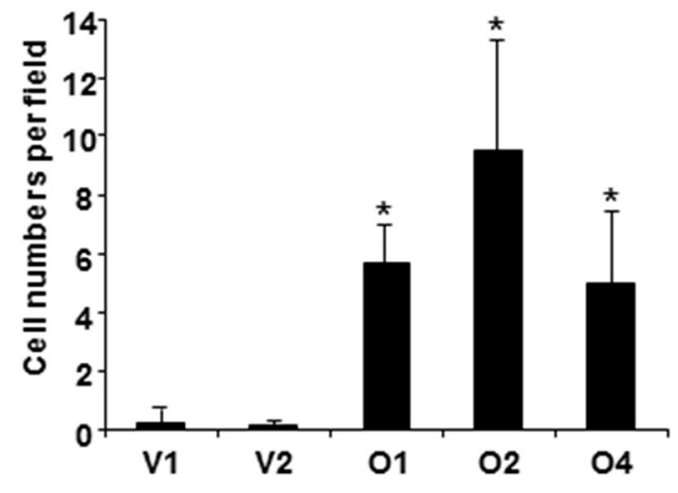

Figure 1: Overexpression of $B P 1$ in MCF-7 cells is associated with aggressiveness. (A) Growth in the absence of serum. V1, $\mathrm{O} 2$ and $\mathrm{O} 4$ cell lines were grown without serum for seven days and cell number was measured using MTT assays. Data was normalized against day 0 , which was set as $100 \%$. Asterisks denote a statistical significance of $p<0.05$ as compared to V1. (B) Colony formation in soft agar. V1, O2 and $\mathrm{O} 4$ cell lines were grown in soft agar as described in Materials and Methods. (C) Photomicrographs of cells grown in soft agar for four or 13 days. (D) Invasion of cells through Matrigel. BP1 overexpressing cell lines (O2 and O4) exhibited higher invasiveness compared to the empty vector control cell lines (V1) $(p<0.05)$. Three fields of unit area on each membrane were counted for cell numbers and the experiments were repeated twice. 
stably transfected with $B P 1$ (O2 or O4) were able to form tumors in the absence of estrogen, in contrast to $0 \%$ of mice injected with V1 cells (Table 1), but this difference was not statistically significant, probably due small sample size. Thus, BP1 overexpression in MCF-7 cells may induce estrogen-independent tumorigenesis in mice.

\section{$B P 1$ regulates $E R$ via two mechanisms}

\section{Direct regulation}

A computer search revealed a consensus BPI binding site [7] located in the first intron (IVS1) of the ER gene. An electrophoretic mobility shift assay (EMSA) verified that BPl binds to this site in vitro. The consensus-binding site within a short stretch of IVS1 was used as a probe. As shown in Figure 4A, BPl binds to the probe (lane 2, arrow). The shifted band is specific, demonstrated by competition with the unlabeled probe
DNA (lanes 3 and 4) but not with non-specific DNA (lanes 5 and 6). A ChIP assay was performed to validate the EMSA results. DNA was precipitated using the $B P 1$ antibody (anti-BP1) with O2 DNA or whole DNA (input) as positive controls, but not the IgG negative control (IgG control) (Figure 4B). The relative quantity of IVS1 precipitated by $B P 1$ antibody is much higher in $\mathrm{O} 2$ cells than in V1 cells. The qRT-PCR data (Figure $4 \mathrm{C},{ }^{*} p<0.01$ ) and Western blot analysis (Figure 4D) suggest that binding of BP1 transcriptionally upregulates ER.

\section{Indirect regulation}

Previously, we showed that $B P 1$ negatively regulates $B R C A 1$ [6]. $P 300$ is a known histone acetyl transferase (HAT) protein which shares a dynamic relationship with $B R C A 1$ and $E R[17,18]$. This led us to investigate the relationship between $B P 1$ and $p 300$. We found a putative $B P 1$ binding region in the first intron of the EP300 gene.

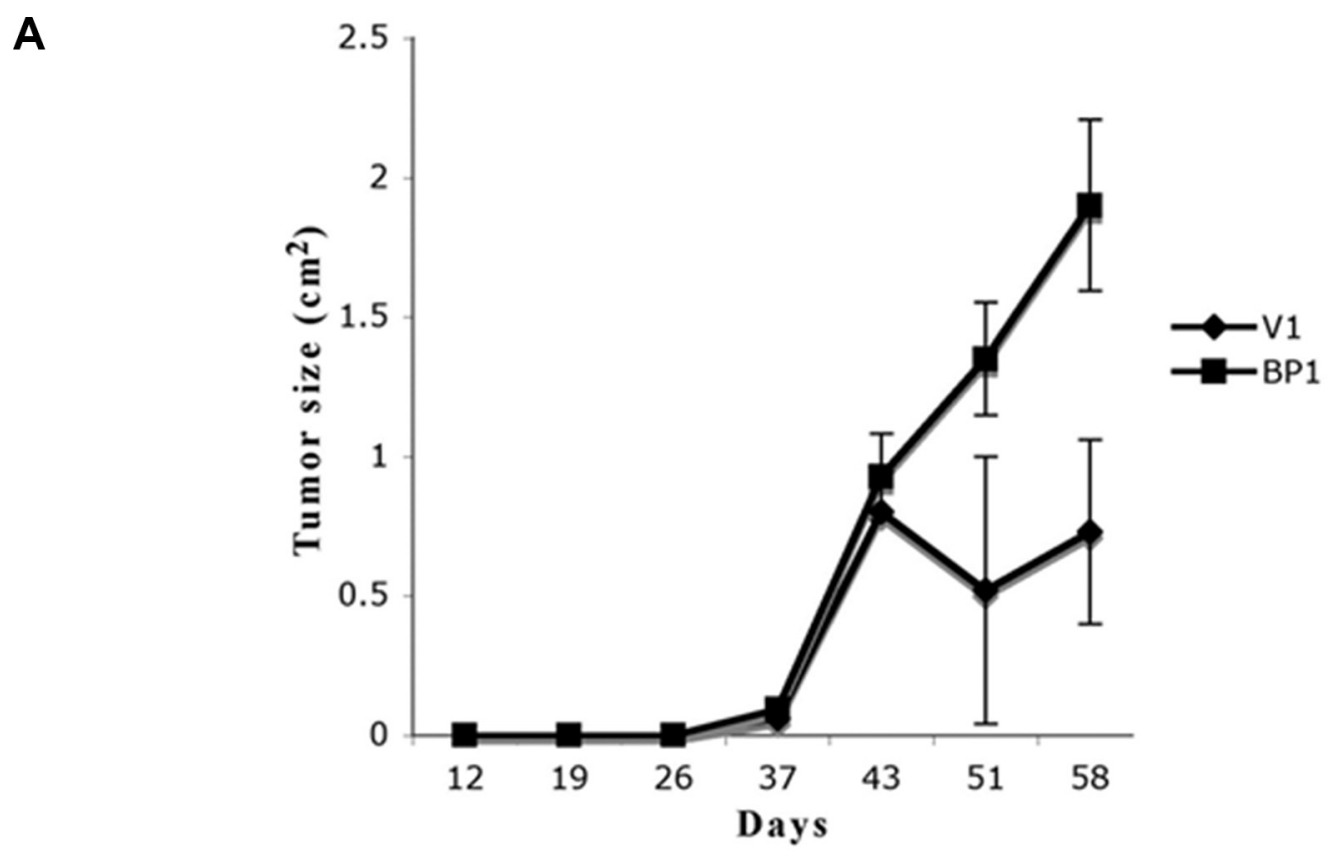

B

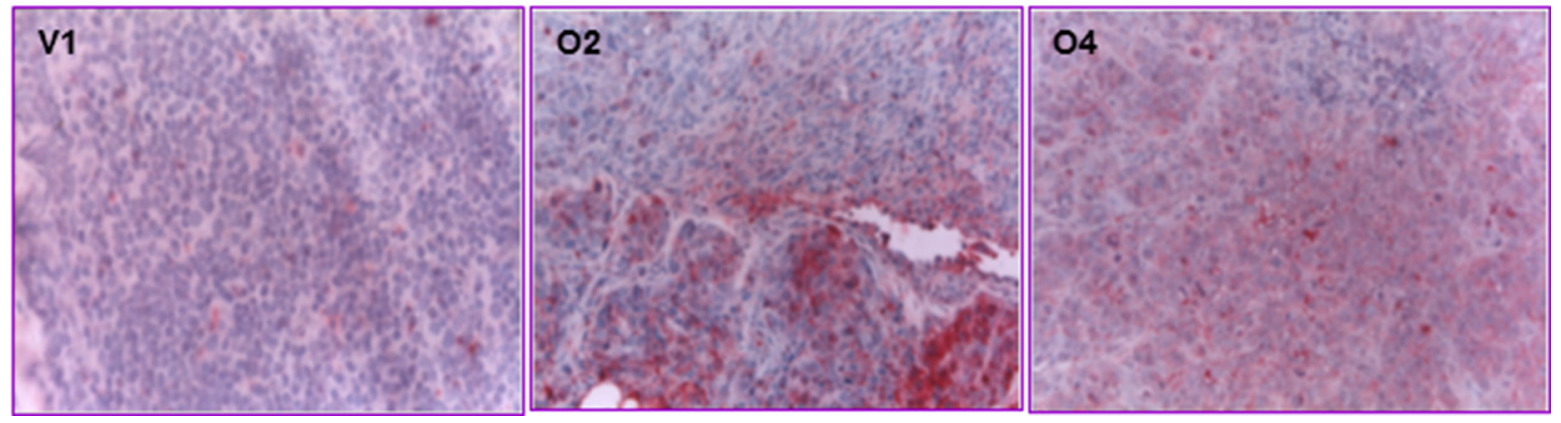

Figure 2: Tumor growth in mice is enhanced by increased BP1 expression. (A) Tumor size. Nude mice supplemented with a cholesterol-based estrogen pellet were injected in the cleared mammary fat pad with V1, O2 or O4 cell lines. Tumors were measured twice weekly and allowed to grow up to 58 days. (B) Immunostaining of tumors with anti- $B P 1$ antibody. Anti- $B P 1$ antibody was used to immunostain tumor sections. Since no tumors derived from V1 cells formed in the absence of an estrogen supplement, all sections are from estrogen supplemented mice. Figures are shown at 300X magnification. 
Table 1: Estrogen dependence of mammary tumor formation in mice correlates with BP1 expression

\begin{tabular}{|c|c|c|}
\hline Cell Type Injected & With Estrogen & Without Estrogen \\
\hline V1 & $4 / 10(40 \%)$ & $0 / 10(0 \%)$ \\
\hline $\mathrm{O} 2$ & $10 / 15(67 \%)$ & $2 / 10(20 \%)$ \\
\hline $\mathrm{O} 4$ & $7 / 11(64 \%)$ & $2 / 10(20 \%)$ \\
\hline
\end{tabular}

MCF-7 cell lines $\mathrm{O} 2$ and $\mathrm{O} 4$, which overexpress $B P 1$, were compared with $\mathrm{V} 1$, a cell line containing the empty vector. The percentage of mice in each category is shown in parentheses.

A ChIP assay was performed to verify the binding of $B P 1$ to the first intron of $P 300$. Figure $5 \mathrm{~A}$ and $5 \mathrm{~B}$ show that $\mathrm{BP} 1$ binds to the $P 300$ gene in the first intronic region in MCF-7 cell derivatives and T47D cell lines, respectively. T47D cells are $E R+$ cell lines that have high endogenous levels of $B P 1$ proteins [8]. $B P 1$ binding is significantly higher in $\mathrm{O} 2$ cells than in V1 cells (Figure 5A). The qRTPCR data (Figure $5 \mathrm{C}, * p<0.05$ ) and Western blot analysis (Figure 5D) show increased expression of $p 300$ in cells overexpressing $B P 1(\mathrm{O} 2)$ compared to V1 cells. Each experiment was repeated at least three times. Thus, $B P 1$ transcriptionally upregulates $P 300$.

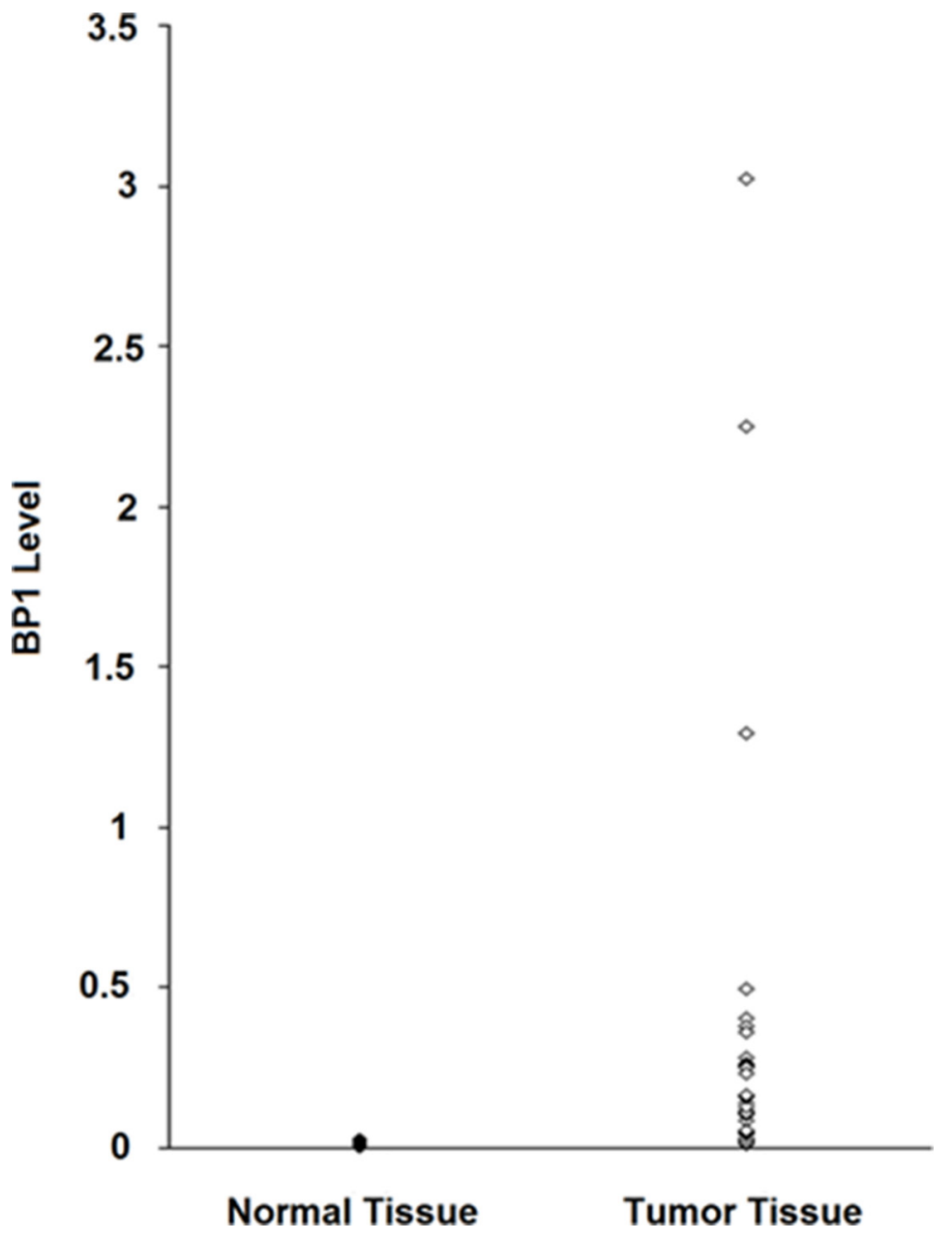

Figure 3: BP1 expression levels in breast tumors. RNA was extracted from 31 frozen tumors, followed by real-time PCR analysis. $B P 1$ levels were normalized to $18 S$ RNA. For comparison, RNA was extracted from five normal frozen breast tissues. 
means are consistently higher than the V1 means, with the only overlap in confidence intervals occurring on Day 7. Factorial analysis of covariance showed that the Condition $\mathrm{x}$ Day interaction was not statistically significant $(p=0.33)$. The lack of interaction between Condition and Day are apparent in Figure 6A, where the time trends are very similar for the $\mathrm{O} 2$ and $\mathrm{V} 1$ conditions.

Real-time PCR was used to determine the levels of BCAR1 mRNA, a marker of tamoxifen resistance [19], comparing V1 and O2 cells. As can be seen from Figure 6B, BCAR1 expression was almost two fold higher in $\mathrm{O} 2$ than in V1 cells $(p<0.01)$.

\section{DISCUSSION}

By a number of different measures, MCF-7 cells overexpressing $B P 1$ were more aggressive: they grew in the absence of serum, formed larger colonies in soft agar, were relatively more infiltrative in an invasion assay and

A

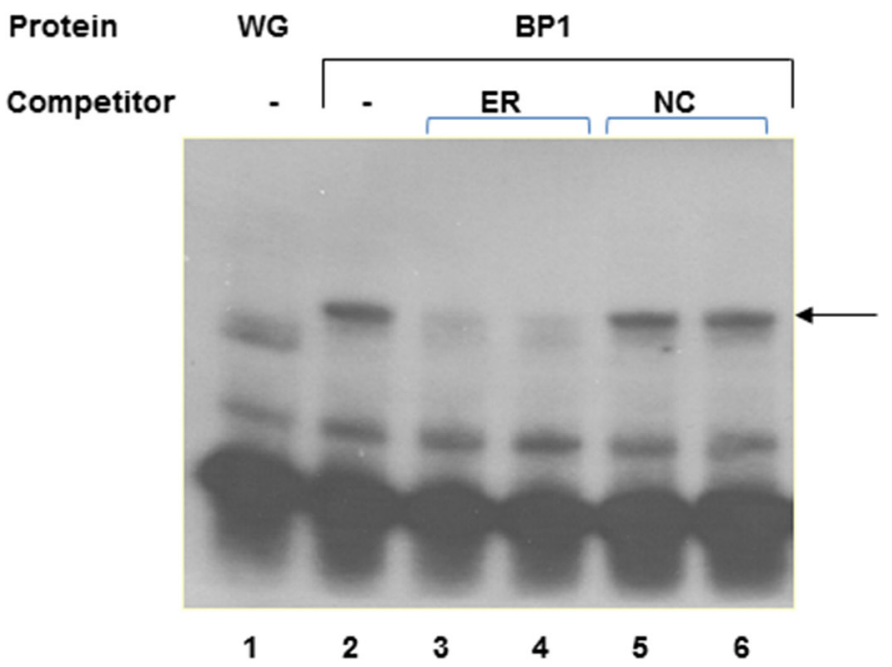

B

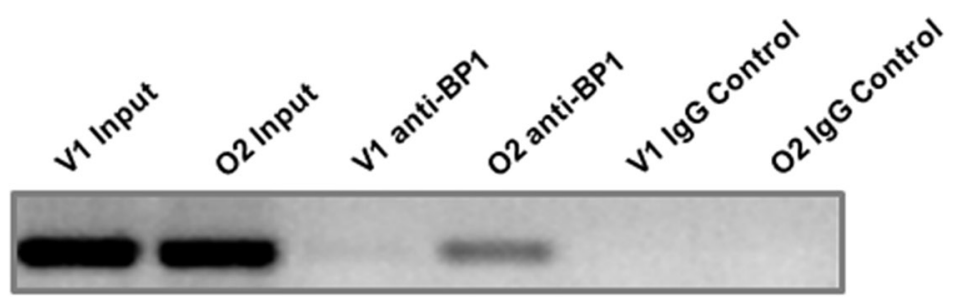

could form tumors in mice without external estrogen supplementation. This result was consistent with our earlier findings that $B P 1$ positive breast tumors have a higher proliferation rate than $B P 1$ negative tumors [9]. We also demonstrated in our earlier study that overexpression of BP1 significantly enhanced cell proliferation and metastatic potential in ER-negative Hs578T cells [15].

The observation that tumors developed in mice without estrogen supplementation was intriguing. Mechanisms of estrogen independence/tamoxifen resistance are not yet fully understood. Evidence in the literature points out that tumors acquire tamoxifen resistance in variety of ways, including but not limited to constitutive activation of $E R$ by phosphorylation via increased growth factor signaling (nongenomic signaling pathway), leading to ligand independent activation of $E R$ and thus insensitivity to estrogen, increased expression of co-activators, conversion of $E R$ positive cells to $E R$ negativity, lack of the $46 \mathrm{kDa} E R$ protein, presence of the $36 \mathrm{kDa} E R$ protein [20-24] or inappropriate increases in

\section{C}

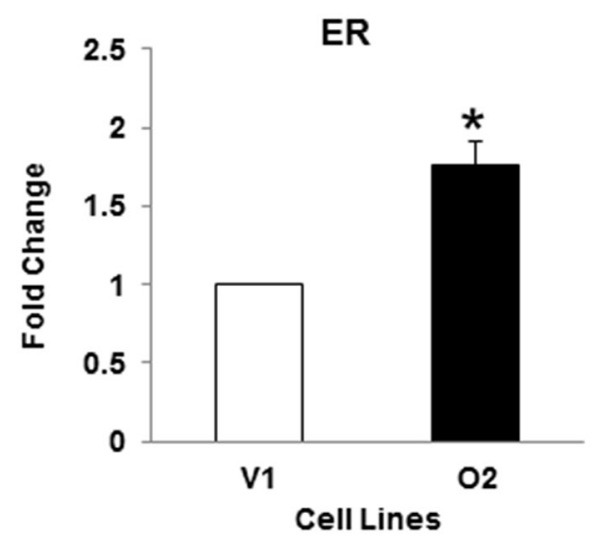

D

V1

02

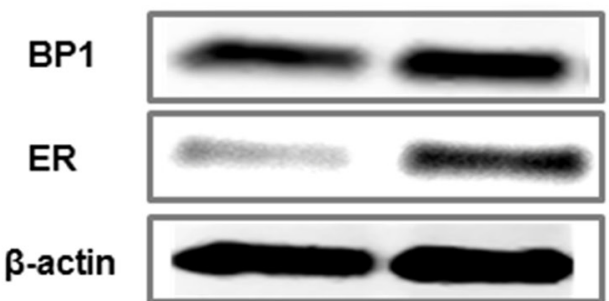

Figure 4: BP1 binds to and regulates $\boldsymbol{E R}$. (A) Binding of BP1 to IVS1 of the estrogen receptor. Electrophoretic mobility shift assays were performed to detect potential binding of in vitro transcribed and translated $B P 1$ to a consensus binding sequence located in IVS1 of the estrogen receptor. Binding of $B P 1$ to a ${ }^{32} \mathrm{P}$ end-labeled dsDNA probe containing the putative $B P 1$ binding site and surrounding sequence is observed as a shifted band (arrow). Lane 1, wheat germ extract (WG) alone incubated with the probe. Lane 2, $B P 1$ incubated with the probe. Lanes 3 and 4, unlabeled $E R$ DNA $(E R)$ was added to the incubation mixture containing $B P 1$ protein at $500 \mathrm{X}$ or $1000 \mathrm{X}$ molar excess, respectively. Lanes 5 and 6, a nonspecific negative control (NC) DNA to which $B P 1$ protein does not bind was added at a $500 \mathrm{X}$ or $1000 \mathrm{X}$ molar excess. (B) ChIP assay. DNA was precipitated using either the BP1 antibody (anti-BP1) or IgG negative control (IgG control) and whole DNA as positive control (input). The quantity of IVS1 DNA precipitated by $B P 1$ antibody was compared in $B P 1$ overexpressing cells (O2) and the empty vector (V1). (C) qRT-PCR. mRNA level of ER was measured by qRT-PCR comparing empty vector (V1) and BP1 overexpressor $(\mathrm{O} 2)(* p<0.01)$. Experiments were performed in triplicate. (D) Western blot analysis. Immunoblotting was performed with protein extracts from V1 and $\mathrm{O} 2$ cells as described in Materials and Methods. 
$E R$ protein levels via increased stability [25-28]. Tamoxifen resistance/estrogen independence in $B P 1$ overexpressing cells is due in part to increased stability. Also, ER, p300 and $B R C A 1$ share a dynamic relationship, with $B R C A 1$ inhibiting $E R$ via ubiquitination, and $p 300$ competitively stabilizing $E R$ via acetylation $[17,29,30]$. Here we found that $B P 1$ activates $E P 300$; it is known that $B P 1$ represses $B R C A 1$ [6]. Thus, $B P 1$ increases $E R$ protein levels by both (i) a direct mechanism: $B P 1$ transcriptionally upregulates $E R$ and (ii) an indirect mechanism: $B P 1$ transcriptionally upregulates p300, thus aiding increased stability of ER (Figure 7). We also demonstrate that cells overexpressing $B P 1$ are more resistant to tamoxifen and express the tamoxifen resistant marker $B C A R 1$; we have found a consensus $B P 1$ binding site in $B C A R 1$, suggesting that $B P 1$ may directly regulate $B C A R 1$.

Other HB genes have been implicated in an altered response to tamoxifen. Breast cancer cells overexpressing $H O X B 7$ or HOXB13 show repression of the estrogen receptor leading to estrogen independence and resistance to tamoxifen $[31,32]$. In contrast, here we show that $B P 1$, also a HB gene, has the ability to confer tamoxifen insensitivity by both transcriptionally upregulating and stabilizing ER protein.

Our previous data demonstrated that the frequency of $B P 1$ positivity, and the distribution and intensity of $B P 1$ expression, increased with the progression of tumor development (normal $\rightarrow$ hyperplasia $\rightarrow$ in situ $\rightarrow$ invasive), from a few randomly distributed $B P 1$ positive cell clusters in normal controls to the vast majority of cells in the invasive tumors showing distinct $B P 1$ immunoreactivity [9]. Other indicators of relative aggressive behavior are associated with $B P 1$ expression in breast tumors. BP1 positivity is associated with (i) high tumor grade [33], a classical indicator of tumor aggressiveness [34]; (ii) tumors of African American women [8], known to show relative aggressive clinical behavior and associated with increased mortality [35, 36]; (iii) inflammatory breast cancer (IBC), a form of breast cancer with poor survival $[37,38]$, where we found that $100 \%$ of IBC tumors were
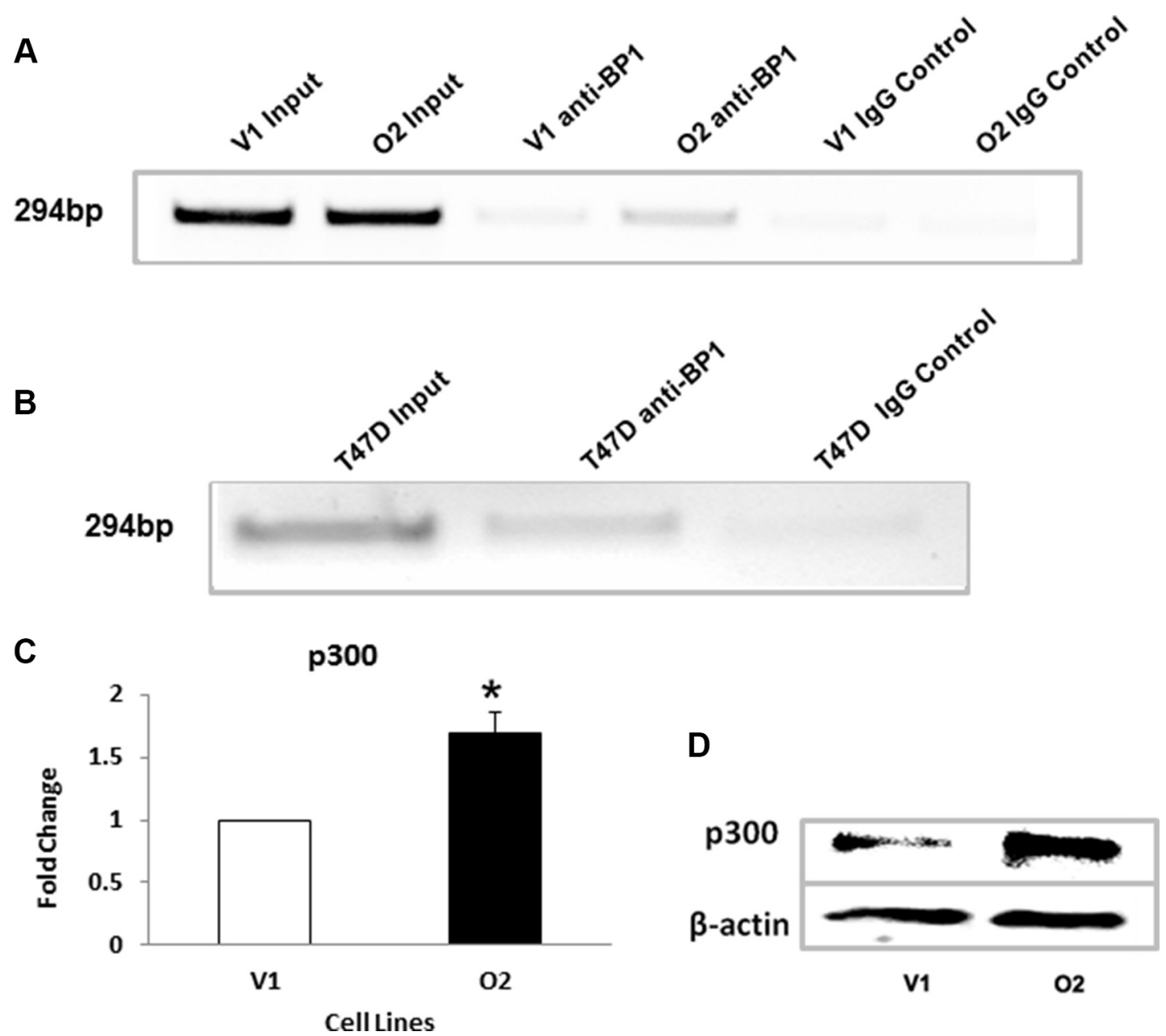

Figure 5: BPI binds to and upregulates EP300. (A, B) ChIP assays. Chromatin immunoprecipitation was performed as described above to verify the binding of BP1 to the first intron of the EP300 gene in MCF-7 cell derivatives and T47D cell lines, respectively. (C) qRT-PCR. mRNA levels of p300 were measured by qRT-PCR comparing MCF-7 cells containing an empty vector (V1) and cells overexpressing $B P 1(\mathrm{O} 2)\left({ }^{*} p<0.05\right)$. Experiments were performed in triplicate. (D) Western blot analysis. Immunoblotting was performed to determine the levels of $p 300$ protein expression in V1 and $\mathrm{O} 2$ cells. 


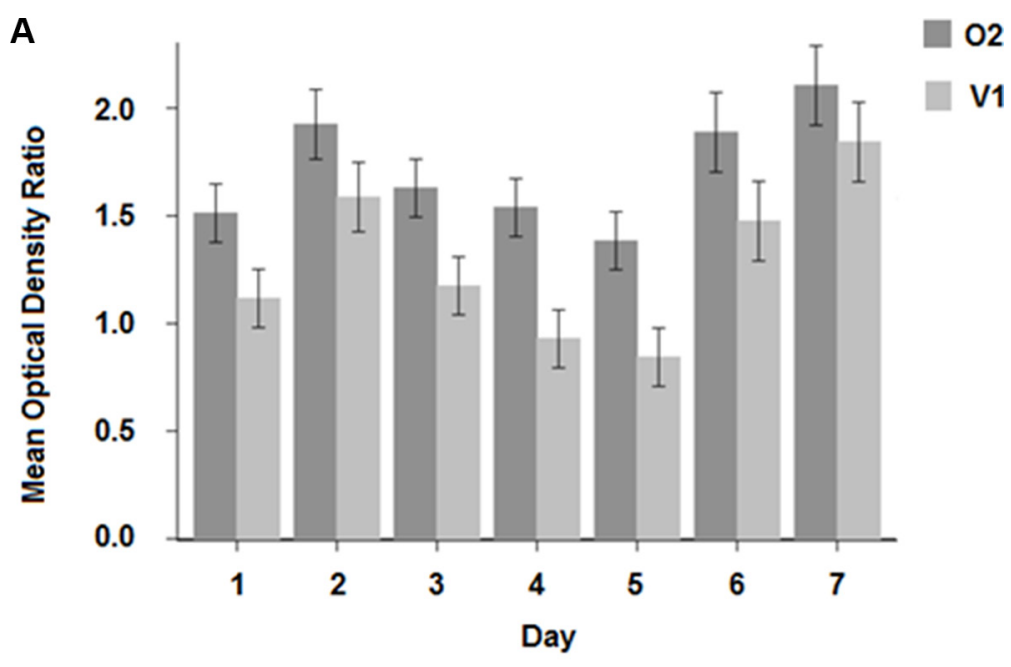

B

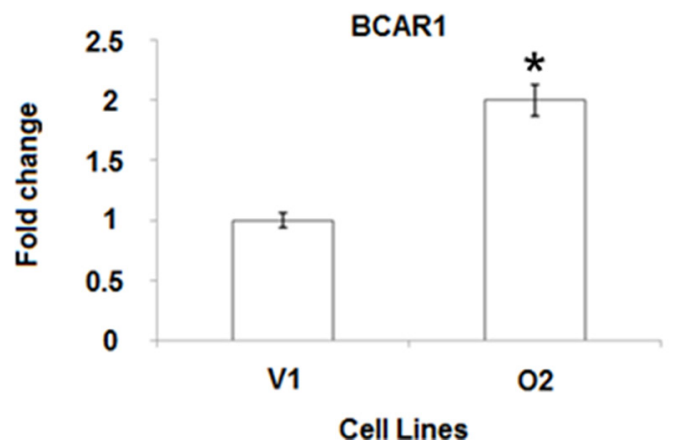

Figure 6: BP1 increases tamoxifen resistance. (A) MTT assay. V1 and O2 cells were challenged with 3 uM tamoxifen over seven days, as described in Materials and Methods. The 95\% confidence limits are shown on the adjusted means. (B) mRNA levels of the tamoxifen resistance marker, $B C A R 1$ (breast cancer anti-resistance). BP1 O2 cells have increased levels of BCAR1 mRNA compared with V1 cells $(* p<0.01)$

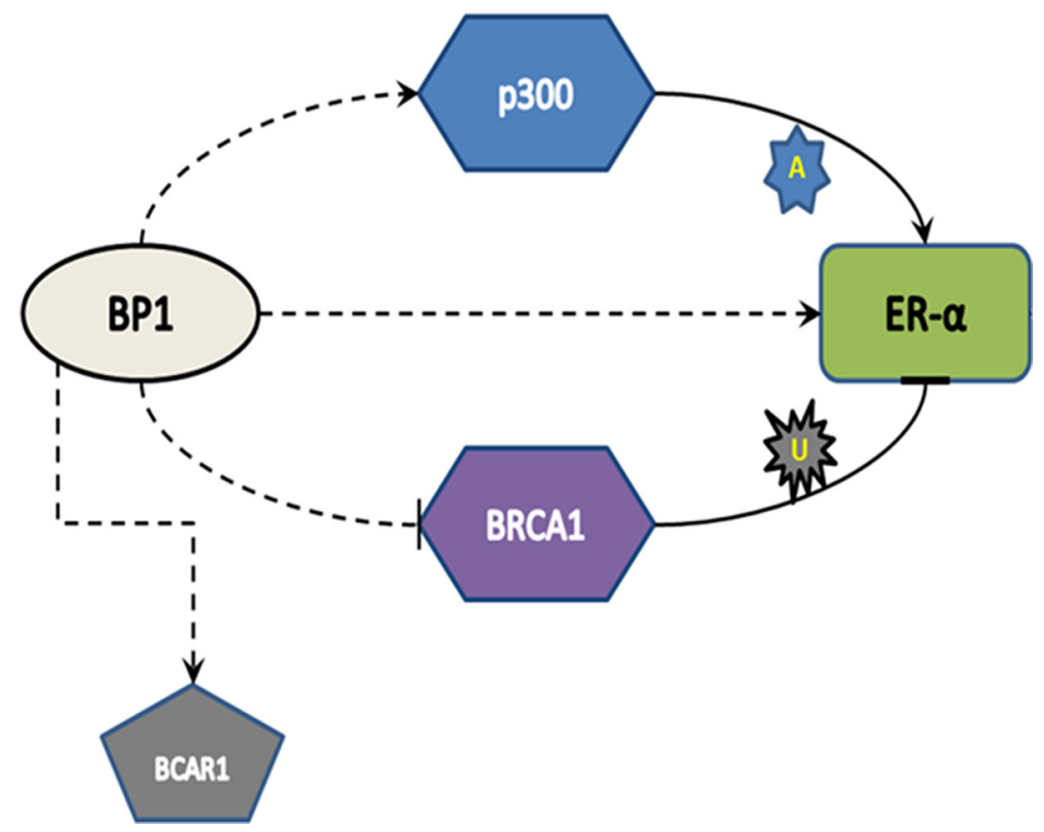

Figure 7: Model of $\boldsymbol{B P 1}$ regulation of $\boldsymbol{E R}$. Dotted lines indicate a transcriptional mechanism, while solid lines indicate translational control (A: acetylation, U: Ubiquitination). BPI binds to and activates EP300; p300 protein, which acetylates and "rescues" ER from $B R C A 1$-mediated ubiquitination, is then up-regulated. Simultaneously, BPl binds and transcriptionally activates $E R$. The increased $E R$ protein expression and stability result in increased tamoxifen resistance. 
$B P 1$ positive, as well as nine lymph nodes from $B P 1$ positive, metastatic IBC tumors [39]; (iv) increased expression of the proliferation marker Ki67 in BPI positive breast and prostate tumors $[9,40]$; (v) decreased apoptosis due to increased expression of $B C L-2$ [12]; (vi) increased expression of $V E G F$ in $B P 1$ positive ovarian tumors (BP1 is called DLX4 in Hara et al. [41]). ChIPon-chip (Chromatin Immunoprecipitation on microarray promoter chip) combined with expression microarray studies have demonstrated that $B P 1$ may regulate VEGF expression in Hs578T breast cancer cells as well [42]; (vii) epithelial to mesenchymal transition [43]. $B P 1$ is expressed in a high percentage of $E R$ negative tumors as well [8]. Here we show that $B P 1$ overexpression correlates with increased metastatic potential, larger tumor size, less dependence on growth factors and resistance to tamoxifen treatment. A picture of the possible clinical importance of $B P 1$ is now emerging.

Based on gene expression profiles, attempts have been made to classify breast tumors, with luminal A being most common subtype of breast cancer representing almost $50-60 \%$ of all diagnosed cases [44]. Luminal A tumors are generally characterized by low expression of the proliferation marker Ki67, sustained expression of $E R, P R$ and $B C L-2$ and generally low $H E R 2$ expression [44, 45]. These types of tumors tend to have a more favorable tumor biology, good prognosis, low histological grade, respond well to tamoxifen/ endocrine therapy and form smaller tumors [45]. Luminal B tumors constitute between $10-20 \%$ of all breast cancer cases. There are a number of characteristics in common between Luminal $\mathrm{B}$ tumors and $B P 1$ positive tumors, as illustrated in this paper: (a) increased expression of proliferation genes, such as Ki67 [9, 44, 45]; (b) $E R+, H E R 2+/-$ and $P R+/-$ in Luminal B tumors and frequent $(73 \%) B P 1$ positivity in $E R+$ tumors [8, $44,45]$; (c) poor prognosis and high grade [33, 44, 45]; (d) reduced sensitivity to tamoxifen ([44, 45] and shown here associated with $B P 1$ levels) and (e) larger tumors $([44,45]$ and shown here for $B P 1)$. Therefore, we speculate that $B P 1$ overexpression in Luminal A subtype cells can "propel" those cells to display more Luminal B-like characteristics. Further study with clinical patient samples is necessary to determine whether $B P 1$ is a biomarker for Luminal B type tumors.

Our current data, along with previously published data, suggest that not only does $B P 1$ expression increase with breast tumor progression but it is also involved in regulating gene expression patterns in tumors, driving them towards a more aggressive subtype. In particular, increased BP1 expression is associated with larger tumors, increased invasiveness of MCF-7 cells, and possibly with increased resistance to tamoxifen. Future clinical studies will provide important insights on $B P I$ as a biomarker and potential therapeutic target in $E R$ positive breast cancer.

\section{MATERIALS AND METHODS}

\section{Cell lines and viability assays}

MCF-7 cells and derivatives that overexpress $B P 1$ were described [12]. MCF-7 cells, as well as the empty vector and BP1 overexpressing MCF-7 cell lines, were maintained in RPMI 1640 containing 10\% FBS and 1\% penicillin/streptomycin $(\mathrm{P} / \mathrm{S})$, supplemented with $500 \mu \mathrm{g} /$ $\mathrm{ml}$ of G418. For viability assays, 2000 cells/well were seeded in triplicate in a 96-well plate and allowed to attach overnight. Media was replaced with serum-free RPMI 1640 the next day and was changed on day 3. For tamoxifen assays, 2000 cells/wells were seeded in a 96well plate and allowed to attach overnight. The media was replaced with phenol red free RPMI 1640 containing 5\% charcoal stripped serum (CSS) and 1\% P/S. The media was changed after 24 hours and $3 \mu \mathrm{M}$ tamoxifen was added (Sigma, St. Louis, MO, USA). Tamoxifen containing media was replaced every 48 hours and readings were taken from day 1 to day 7 . Growth was measured by the 3-(4,5-dimethylthiazol-2-yl)-(2,3-diphenyltetrazolium) bromide dye conversion assay (Sigma) at $570 \mathrm{~nm}$. T47D cell lines were grown and maintained in RPMI 1640 containing $10 \%$ FBS and $1 \%$ penicillin/streptomycin.

\section{Cell growth in soft agar}

12,500 cells $/ \mathrm{ml}$ were suspended in $0.3 \%$ agar supplemented with DMEM and 10\% FBS and layered over $1 \mathrm{ml}$ of a $0.8 \%$ agar/medium base [46]. Cells were allowed to grow over a 14-day period; colonies were stained with nitroblue tetrazolium and counted using an Artek 880 colony counter.

\section{Invasion assays}

The cell invasive capacity was estimated using BioCoat Matrigel Invasion Chambers $(8 \mathrm{~mm}$ pores, 24 wells) (BD Bioscience, Bedford, MA, USA) as described previously [15]. In brief, cells stably transfected with an empty vector or with $B P 1$ cDNA plasmids were resuspended in serum-free DMEM medium $\left(2.5 \times 10^{5} \mathrm{cells} / \mathrm{ml}\right)$ and seeded in the top chamber of prewet inserts. After $48 \mathrm{~h}$ incubation, cells that migrated to the bottom surface of the insert were stained with DiffQuick staining solution and quantified. The number of migrating cells was determined by counting five nonoverlapping random fields on each chamber; four to five chambers were counted for each experimental point.

\section{Tumor formation in mice}

The use of mice in this study was approved by the NIH Institutional Animal Care and Use Committee (IACUC). All procedures were conducted in accordance 
with the NIH Guide for the Care and Use of Laboratory Animals. Athymic nude mice were maintained on a $12 \mathrm{hr}$ light $/ 12 \mathrm{hr}$ dark schedule with free access to laboratory chow and water. $2 \times 10^{6} \mathrm{cells}$ were injected into the cleared mammary fat pads of 4-6 week old female athymic nude mice [47]. At the same time, some of the mice were also implanted subcutaneously with a $10 \mathrm{mg}$ cholesterol-based pellet containing $0.72 \mathrm{mg}$ of $17-\beta$-estradiol (Innovative Research of America, Sarasota, FL, USA). Tumors were measured at the indicated times in two dimensions using calipers. At sacrifice, tumors were either frozen or fixed in $10 \%$ normal buffered formalin.

\section{Clinical samples}

Human breast tumor samples were obtained from The George Washington University Department of Pathology with IRB approval. Breast tissue samples $0.5-1.0 \mathrm{~cm}$ in diameter were obtained from frozen surgical resection specimens and characterized pathologically.

\section{Electrophoretic mobility shift assays (EMSA) assays}

EMSA was performed as described earlier $[6,7]$. Complementary sequences in the first intervening sequence (IVS1) of the ER were annealed and 5'-endlabeled with ${ }^{32} \mathrm{P}$-ATP using T4 kinase (Invitrogen, Grand Island, NY, USA). The Wheat Germ Coupled Transcription /Translation kit (Promega, Madison, WI, USA) was used to generate $B P 1$ protein from the plasmid pGEM7 containing the $B P 1$ open reading frame. Unlabeled competitor oligonucleotides were added at $500 \mathrm{X}$ or $1000 \mathrm{X}$ molar excess to the binding reactions. The following DNA sequences were used as probes: $E R$ :

5'-GGCAAAATGCAGCTCTTCCTATATGTATAC CCTGAATCTC-3'; negative control (NC): 5'-TCTTAGAGGGAGGGCTGAGGGTTTGAAG TCCAACTCCTAAGCC-3'.

\section{Chromatin-immunoprecipitation (ChIP) assays}

The $B P 1$ consensus binding site (5'-WTCWATATG-3') on EP300 [7] was predicted using the CISTER program [48]. Primers, flanking the putative $B P 1$ binding site, were designed using primer3plus [49] tool and verified by primer-BLAST [50]. The primers used for ChIP assay are as follows: 5'-GGAGCATCCTCAGATTTTGG-3' (EP300Forward) and 5'-TGCCTTAACTATCTGCTGATTTTC-3' (EP300-Reverse). The ChIP protocol was performed using the Millipore ChIP kit (Millipore, Billerica, MA, USA) as described previously $[6,42]$. Briefly, $B P 1$-overexpressing MCF-7 or T47D cells were crosslinked at $80 \%$ confluence in $10 \mathrm{~mL}$ RPMI 1640 media with $1 \%$ formaldehyde for ten minutes at $37^{\circ} \mathrm{C}$. Cells were washed twice with cold PBS containing $1 \mathrm{x}$ complete mini protease inhibitor
(Roche Applied Science, Indianapolis, IN, USA), lysed in SDS lysis buffer and incubated for fifteen minutes on ice. Chromatin was sheared by sonication for 10 pulses, twice. Equal amounts of DNA were used as test and negative controls, and $1 \mu \mathrm{g}$ was used as the input control. $10 \mu \mathrm{g}$ of BP1 antibody (Bethyl Labs, Montgomery, TX, USA) or equal amounts of normal rabbit IgG (Cell signaling, Danvers, MA, USA ) were added along with salmon sperm DNA/Protein G PLUS/Protein A agarose beads, and incubated overnight at 4C. Further isolation and purification of the precipitated DNA was done according to Millipore's protocol. Isolated DNA was resuspended in Tris-EDTA buffer for use in PCR. Platinum superscript master mix was used with a $10 \mu \mathrm{M}$ final concentration of each primer and $1 \mu \mathrm{g}$ of DNA as input or $5 \mu \mathrm{l}$ of isolated/ precipitated DNA in a final reaction volume of $45 \mu 1$. PCR was run for 40 cycles. The PCR product was analyzed on a $2 \%$ agarose gel and visualized.

\section{Real-time PCR assays}

Total RNA was prepared using the RNeasy Mini Kit (Qiagen Inc, Valencia, CA. USA). RNA samples underwent DNase I treatment (Promega, Madison, WI, USA) prior to first-strand cDNA synthesis with random hexamer primers using the Superscript II First-Strand cDNA Synthesis System (Invitrogen, Grand Island, NY, USA). Real-time PCR was carried out using the ABI 7300 model sequence detection system (Applied Biosystem, Foster City, CA, USA) with SYBR Green I PCR Mastermix (BioRad, Hercules, CA, USA). Primers for ER and EP300 were published [51-53]. Primers for $B P 1$ were designed using Primer-BLAST and are as follows: 5'-CCTCCCCCAATTTGTCCTACTC-3' (forward) and 5'-GGTTGCTGGCAGGACAGGTA-3' (reverse). The amplification program included an initial denaturation at $95^{\circ} \mathrm{C}$ for $10 \mathrm{~min}$., followed by 40 cycles of a two-stage PCR consisting of $95^{\circ} \mathrm{C}$ for $15 \mathrm{~s}$ and $60^{\circ} \mathrm{C}$ for $1 \mathrm{~min}$. Specificity for PCR amplifications was verified by observing a single peak dissociation curve for each gene. One microliter of the reverse transcribed cDNA was used for each real-time PCR reaction and all reactions were performed in triplicate. The expression values of genes from different samples were calculated by normalizing with 18S RNA and relative quantitation values were plotted.

\section{Immunoblotting assays}

Cells were grown to $70 \%-80 \%$ confluency and proteins extracted as previously described [12]. 30-65 $\mu \mathrm{g}$ of proteins were loaded on 4-20\% SDS-PAGE gels (Bio-Rad, Hercules, CA, USA) and transferred to nitrocellulose membranes. Blots were probed overnight with rabbit anti-BPI (Bethyl Labs, Montgomery, TX, USA) at a 1:5000 dilution, with rabbit antiER- $\alpha$ (Bethyl 
labs, Montgomery, TX, USA) at a 1:1000 dilution, mouse anti-p300 (Millipore, Billerica, MA, USA) at a 1:500 dilution, or mouse anti-beta-actin (Sigma, St. Louis, MO, USA) at a 1:5000 dilution. After washing, blots were incubated with either horseradish peroxidase-linked goat anti-mouse (1:2500 dilution) or goat anti-rabbit secondary antibodies (1:15,000 dilution). Signals were detected using SuperSignal West Dura Extended Duration Substrate (Pierce, Rockford, IL, USA).

\section{Statistical analyses}

For analysis of mouse data, due to the smaller sample sizes, data were first pooled for the mice receiving the two BPl-overexpressing cell lines when tested against the control mice. For the test of colony size differences, results are based on the pooled data from six independent replications (two experimental replications of three wells each). For tamoxifen experiments, in order to adjust for any ethanol (EtOH) effects on optical density, scores were calculated by subtraction (subtracting mean optical density under the EtOH condition for each day for $\mathrm{O} 2$ and V1 from the tamoxifen condition scores) and by ratio (dividing the tamoxifen condition scores by the mean optical density under the EtOH condition for each day for $\mathrm{O} 2$ and V1). The ratio adjustment method was used for all subsequent analyses because of greater homoscedasticity and reasonable evidence of normality. The statistical test of mean differences on study condition (O2 vs V1), follow-up day, and Condition x Day interaction was by factorial analysis of covariance. The qPCR data for $E R$ and $p 300$ were analyzed by one-sample $t$-test.

\section{ACKNOWLEDGMENTS}

We thank Maura Costello and Cassandra Campbell for their excellent technical assistance and Yassi Fallah for assistance with the manuscript.

\section{CONFLICTS OF INTEREST}

The authors declare no competing interests.

\section{GRANT SUPPORT}

Portions of this research were supported by grant K08 CA102875 (JJP), by the Intramural Research Program of the NIH, Center for Cancer Research, NCI (E.G. and B.K.V.), the Elaine H. Snyder Cancer Research Award (SWF) and by the Katherine Birch McCormick Foundation (PEB).

\section{REFERENCES}

1. Abate-Shen C. Deregulated homeobox gene expression in cancer: cause or consequence? Nature reviews. 2002; 2:777-785.
2. Berg PE, Kirolikar SP. DLX4 (distal-less homeobox 4). Atlas Genet Cytogenet Oncol Haematol. 2011; 15:658-661.

3. Care A, Felicetti F, Meccia E, Bottero L, Parenza M, Stoppacciaro A, Peschle C, Colombo MP. HOXB7: a key factor for tumor-associated angiogenic switch. Cancer research. 2001; 61:6532-6539.

4. Raman V, Martensen SA, Reisman D, Evron E, Odenwald WF, Jaffee E, Marks J, Sukumar S. Compromised HOXA5 function can limit p53 expression in human breast tumours. Nature. 2000; 405:974-978.

5. Zhang X, Zhu T, Chen Y, Mertani HC, Lee KO, Lobie PE. Human growth hormone-regulated HOXA1 is a human mammary epithelial oncogene. The Journal of biological chemistry. 2003; 278:7580-7590.

6. Kluk BJ, Fu Y, Formolo TA, Zhang L, Hindle AK, Man YG, Siegel RS, Berg PE, Deng C, McCaffrey TA, Fu SW. BP1, an isoform of DLX4 homeoprotein, negatively regulates BRCA1 in sporadic breast cancer. Int J Biol Sci. 2010; 6:513-524.

7. Chase MB, Fu S, Haga SB, Davenport G, Stevenson H, Do K, Morgan D, Mah AL, Berg PE. BP1, a homeodomaincontaining isoform of DLX4, represses the beta-globin gene. Molecular and cellular biology. 2002; 22:2505-2514.

8. Fu SW, Schwartz A, Stevenson H, Pinzone JJ, Davenport GJ, Orenstein JM, Gutierrez P, Simmens SJ, Abraham J, Poola I, Stephan DA, Berg PE. Correlation of expression of BP1, a homeobox gene, with estrogen receptor status in breast cancer. Breast Cancer Res. 2003; 5:R82-87.

9. Man YG, Fu SW, Schwartz A, Pinzone JJ, Simmens SJ, Berg PE. Expression of BP1, a novel homeobox gene, correlates with breast cancer progression and invasion. Breast cancer research and treatment. 2005; 90:241-247.

10. Dickson RB, Lippman ME. Growth factors in breast cancer. Endocr Rev. 1995; 16:559-589.

11. Carroll JS, Meyer CA, Song J, Li W, Geistlinger TR, Eeckhoute J, Brodsky AS, Keeton EK, Fertuck KC, Hall GF, Wang Q, Bekiranov S, Sementchenko V, et al. Genome-wide analysis of estrogen receptor binding sites. Nature genetics. 2006; 38:1289-1297.

12. Stevenson HS, Fu SW, Pinzone JJ, Rheey J, Simmens SJ, Berg PE. BP1 transcriptionally activates bcl-2 and inhibits TNFalpha-induced cell death in MCF7 breast cancer cells. Breast Cancer Res. 2007; 9:R60.

13. Hanahan D, Weinberg RA. The hallmarks of cancer. Cell. 2000; 100:57-70.

14. Holst-Hansen C, Johannessen B, Hoyer-Hansen G, Romer J, Ellis V, Brunner N. Urokinase-type plasminogen activation in three human breast cancer cell lines correlates with their in vitro invasiveness. Clinical \& experimental metastasis. 1996; 14:297-307.

15. Fu Y, Lian Y, Kim KS, Zhang L, Hindle AK, Brody F, Siegel RS, McCaffrey TA, Fu SW. BP1 Homeoprotein Enhances Metastatic Potential in ER-negative Breast Cancer. J Cancer. 2010; 1:54-62. 
16. Osborne CK, Hobbs K, Clark GM. Effect of estrogens and antiestrogens on growth of human breast cancer cells in athymic nude mice. Cancer research. 1985; 45:584-590.

17. Fan S, Ma YX, Wang C, Yuan RQ, Meng Q, Wang JA, Erdos M, Goldberg ID, Webb P, Kushner PJ, Pestell RG, Rosen EM. p300 Modulates the BRCA1 inhibition of estrogen receptor activity. Cancer research. 2002; 62:141-151.

18. Ma Y, Fan S, Hu C, Meng Q, Fuqua SA, Pestell RG, Tomita YA, Rosen EM. BRCA1 regulates acetylation and ubiquitination of estrogen receptor-alpha. Mol Endocrinol. 2010; 24:76-90.

19. van der Flier S, Chan CM, Brinkman A, Smid M, Johnston SR, Dorssers LC, Dowsett M. BCAR1/p130Cas expression in untreated and acquired tamoxifen-resistant human breast carcinomas. Int J Cancer. 2000; 89:465-468.

20. Sarwar N, Kim JS, Jiang J, Peston D, Sinnett HD, Madden P, Gee JM, Nicholson RI, Lykkesfeldt AE, Shousha S, Coombes RC, Ali S. Phosphorylation of ERalpha at serine 118 in primary breast cancer and in tamoxifen-resistant tumours is indicative of a complex role for ERalpha phosphorylation in breast cancer progression. Endocrinerelated cancer. 2006; 13:851-861.

21. Guo JP, Shu SK, Esposito NN, Coppola D, Koomen JM, Cheng JQ. IKKepsilon phosphorylation of estrogen receptor alpha Ser-167 and contribution to tamoxifen resistance in breast cancer. The Journal of biological chemistry. 2010; 285:3676-3684.

22. Fowler AM, Santen RJ, Allred DC. "Dwarf" estrogen receptor in breast cancer and resistance to tamoxifen. J Clin Oncol. 2009; 27:3413-3415.

23. Shi L, Dong B, Li Z, Lu Y, Ouyang T, Li J, Wang T, Fan Z, Fan T, Lin B, Wang Z, Xie Y. Expression of ER-\{alpha\}36, a novel variant of estrogen receptor $\{$ alpha $\}$, and resistance to tamoxifen treatment in breast cancer. J Clin Oncol. 2009; 27:3423-3429.

24. Klinge CM, Riggs KA, Wickramasinghe NS, Emberts CG, McConda DB, Barry PN, Magnusen JE. Estrogen receptor alpha 46 is reduced in tamoxifen resistant breast cancer cells and re-expression inhibits cell proliferation and estrogen receptor alpha 66-regulated target gene transcription. Mol Cell Endocrinol. 2010; 323:268-276.

25. Schiff R, Osborne CK. Endocrinology and hormone therapy in breast cancer: new insight into estrogen receptor-alpha function and its implication for endocrine therapy resistance in breast cancer. Breast Cancer Res. 2005; 7:205-211.

26. Pinzone JJ, Stevenson H, Strobl JS, Berg PE. Molecular and cellular determinants of estrogen receptor alpha expression. Molecular and cellular biology. 2004; 24:4605-4612.

27. Ali S, Coombes RC. Endocrine-responsive breast cancer and strategies for combating resistance. Nature reviews. 2002; 2:101-112.

28. Fowler AM, Solodin N, Preisler-Mashek MT, Zhang P, Lee AV, Alarid ET. Increases in estrogen receptor-alpha concentration in breast cancer cells promote serine 118/104/106-independent AF-1 transactivation and growth in the absence of estrogen. FASEB J. 2004; 18:81-93.

29. Kim SH, Kang HJ, Na H, Lee MO. Trichostatin A enhances acetylation as well as protein stability of ERalpha through induction of p300 protein. Breast Cancer Res. 2010; 12:R22.

30. Fan S, Wang J, Yuan R, Ma Y, Meng Q, Erdos MR, Pestell RG, Yuan F, Auborn KJ, Goldberg ID, Rosen EM. BRCA1 inhibition of estrogen receptor signaling in transfected cells. Science. 1999; 284:1354-1356.

31. Jin K, Kong X, Shah T, Penet MF, Wildes F, Sgroi DC, Ma XJ, Huang Y, Kallioniemi A, Landberg G, Bieche I, Wu X, Lobie PE, et al. The HOXB7 protein renders breast cancer cells resistant to tamoxifen through activation of the EGFR pathway. Proceedings of the National Academy of Sciences of the United States of America. 2012; 109:2736-2741.

32. Shah N, Jin K, Cruz LA, Park S, Sadik H, Cho S, Goswami CP, Nakshatri H, Gupta R, Chang HY, Zhang Z, Cimino-Mathews A, Cope L, et al. HOXB13 mediates tamoxifen resistance and invasiveness in human breast cancer by suppressing ERalpha and inducing IL-6 expression. Cancer research. 2013; 73:5449-5458.

33. Yu M, Yang Y, Shi Y, Wang D, Wei X, Zhang N, Niu R. Expression level of beta protein 1 mRNA in Chinese breast cancer patients: a potential molecular marker for poor prognosis. Cancer Sci. 2008; 99:173-178.

34. Hanrahan EO, Valero V, Gonzalez-Angulo AM, Hortobagyi GN. Prognosis and management of patients with node-negative invasive breast carcinoma that is $1 \mathrm{~cm}$ or smaller in size (stage 1; T1a,bN0M0): a review of the literature. J Clin Oncol. 2006; 24:2113-2122.

35. Edwards MJ, Gamel JW, Vaughan WP, Wrightson WR. Infiltrating ductal carcinoma of the breast: the survival impact of race. J Clin Oncol. 1998; 16:2693-2699.

36. Mancino AT, Rubio IT, Henry-Tillman R, Smith LF, Landes R, Spencer HJ, Erkman L, Klimberg VS. Racial differences in breast cancer survival: the effect of residual disease. The Journal of surgical research. 2001; 100:161-165.

37. Chang S, Parker SL, Pham T, Buzdar AU, Hursting SD. Inflammatory breast carcinoma incidence and survival: the surveillance, epidemiology, and end results program of the National Cancer Institute, 1975-1992. Cancer. 1998; 82:2366-2372.

38. Baldini E, Gardin G, Evagelista G, Prochilo T, Collecchi P, Lionetto R. Long-term results of combined-modality therapy for inflammatory breast carcinoma. Clinical breast cancer. 2004; 5:358-363.

39. Man YG, Schwartz A, Levine PH, Teal C, Berg PE. BP1, a putative signature marker for inflammatory breast cancer and tumor aggressiveness. Cancer Biomark. 2009; 5:9-17.

40. Schwartz AM, Man YG, Rezaei MK, Simmens SJ, Berg PE. BP1, a homeoprotein, is significantly expressed in prostate adenocarcinoma and is concordant with prostatic intraepithelial neoplasia. Mod Pathol. 2009; 22:1-6. 
41. Hara F, Samuel S, Liu JS, Rosen D, Langley RR, Naora H. A homeobox gene related to Drosophila Distal-less promotes ovarian tumorigenicity by inducing expression of vascular endothelial growth factor and fibroblast growth factor-2. American Journal of Pathology. 2007; 170:1594-1606.

42. Song Y, Dang C, Fu Y, Lian Y, Hottel J, Li X, McCaffrey T, $\mathrm{Fu}$ SW. Genome-wide analysis of BP1 transcriptional targets in breast cancer cell line Hs578T. Int J Biol Sci. 2009; 5:1-12.

43. Zhang L, Yang M, Gan L, He T, Xiao X, Stewart MD, Liu X, Yang L, Zhang T, Zhao Y, Fu J. DLX4 upregulates TWIST and enhances tumor migration, invasion and metastasis. Int J Biol Sci. 2012; 8:1178-1187.

44. Eroles P, Bosch A, Perez-Fidalgo JA, Lluch A. Molecular biology in breast cancer: intrinsic subtypes and signaling pathways. Cancer Treat Rev. 2012; 38:698-707.

45. Creighton CJ. The molecular profile of luminal B breast cancer. Biologics. 2012; 6:289-297.

46. Courtenay VD, Selby PJ, Smith IE, Mills J, Peckham MJ. Growth of human tumour cell colonies from biopsies using two soft-agar techniques. British journal of cancer. 1978; 38:77-81.

47. Deome KB, Faulkin LJ, Jr., Bern HA, Blair PB. Development of mammary tumors from hyperplastic alveolar nodules transplanted into gland-free mammary fat pads of female C3H mice. Cancer research. 1959; 19:515-520.
48. Frith MC, Hansen U, Weng Z. Detection of cis-element clusters in higher eukaryotic DNA. Bioinformatics. 2001; 17:878-889.

49. Untergasser A, Cutcutache I, Koressaar T, Ye J, Faircloth BC, Remm M, Rozen SG. Primer3-new capabilities and interfaces. Nucleic Acids Res. 2012; 40:e115.

50. Ye J, Coulouris G, Zaretskaya I, Cutcutache I, Rozen S, Madden TL. Primer-BLAST: a tool to design targetspecific primers for polymerase chain reaction. BMC Bioinformatics. 2012; 13:134.

51. Ariazi EA, Clark GM, Mertz JE. Estrogen-related receptor alpha and estrogen-related receptor gamma associate with unfavorable and favorable biomarkers, respectively, in human breast cancer. Cancer research. 2002; 62:6510-6518.

52. Bieche I, Parfait B, Tozlu S, Lidereau R, Vidaud M. Quantitation of androgen receptor gene expression in sporadic breast tumors by real-time RT-PCR: evidence that MYC is an AR-regulated gene. Carcinogenesis. 2001; 22:1521-1526.

53. Le Corre L, Fustier P, Chalabi N, Bignon YJ, BernardGallon D. Effects of resveratrol on the expression of a panel of genes interacting with the BRCA1 oncosuppressor in human breast cell lines. Clin Chim Acta. 2004; 344:115-121. 